The second book, "Disposal of Sewage and other Water-Borne Wastes", has had an unusual history, its first ancestor being a text written by Dr. Imhoff in 1906 for the guidance of the team, of which he was chief, which was preparing plans for the sewerage of the Essen district of Germany. Since then it has gone through many editions; in several languages, the present text being based on the sixteenth German edition of 1956. It gives an excellent and welldocumented account of sewage treatment processes, and has two particular virtues-it deals equally thoroughly with German, British, and American practice, and it contains many worked examples of the calculations necessary in designing treatment plant. Indeed, the first English edition was published under the title "The Arithmetic of Sewage Treatment Works".

Both these books are concerned mainly with the treatment of urban wastes, whether domestic or industrial, and are addressed to the engineers, chemists, and biologists who as servants of industrial firms, of local authorities and river boards, or of Government, have to see that they are disposed of without nuisance. "Rural Water Supply and Sanitation", on the other hand, by the professor of agricultural engineering of Cornell University, is for the farmer or builder in a country district who may have to find his own water supply (the use of the divining rod is discouraged), dig his well, install the plumbing, and dispose of the resulting sewage by somewhat primitive methods. There are perhaps not many opportunities now in Britain for practising these arts but the book, which is well written and illustrated, should be very useful to the engineer going to work in an undeveloped territory overseas.

\section{CONSEQUENCES OF SUCCESS}

Some Observations on American Education

By Robert M. Hutchins. Pp. xiii +112. (Cambridge : At the University Press, 1956.) 15s. net.

M. R. M. HUTCHINS has been the enfant I terrible of higher education in the United States for twenty-five years. That is a long tenure for such an iconoclastic office. His latest book establishes anew his claim to the title. He writes with wit and sometimes with an acid pen : and he always has something interesting to say. "Some Observations on American Education" is based on lectures given three years ago in various British universities. It begins with a brief anatomy of the educational system of the United States; it then goes on to examine the ideals, standards, and organization of the system, with special reference to American universities; it has some entertaining things to say about alumni, athletics, and academic freedom; and it ends with some reflexions on the future of education in America.

The purpose of a controversial book is to arouse controversy. Mr. Hutchins's book (which is in this category) will doubtless achieve its purpose. However, there are canons of correctness even in controversy. Controversialists on serious topics should present all the relevant facts fairly and correctly, and concentrate their argument on interpretation of these facts. Mr. Hutchins has not done this. In the introduction he disingenuously says that he could have written quite a different and highly complimentary book about American education "and this approach would have required other illustrations". The book under review confines its illustrations to such items as the Department of Mortuary Science at Wayne University, Detroit, the advanced waiters' course in New York City Community College, California's B.Sc. in television, and the fact that basketball players in one university may "major" in elementary swimming, social dancing, and first aid. No one doubts the accuracy of these indictments ; indeed Abraham Flexner ${ }^{1}$ exposed them more than a quarter of a century ago, also in lectures given to a British audience. No one interested in American education would like to see such indictments suppressed, but if there is to be a reasoned and fruitful discussion over American education indictments need to be studied in perspective, not in isolation. This has recently been done for American higher education in two admirable books, one by Hofstadter and Hardy ${ }^{2}$, and the other by Hofstadter and Metzger ${ }^{3}$. Anyone interested in Mr. Hutchins's thesis would do well to study these two books before reaching any conclusions.

As to the thesis itself, it is important and relevant to our own educational problems in Britain. America has adopted the doctrine of education for all : Is this consistent with the maintenance of high standards ? Mr. Hutchins believes that the answer is "yes" but that all sorts of other factors have conspired to debase the currency of American education; so much so that in the minds of many Americans (so Mr. Hutchins suggests) education is a social device to accommodate the young and keep them amused until they are old enough to work. His message to his British audience, therefore, is : Follow our doctrine of education for all (a little gratuitous, perhaps, in view of the Education Act, 1944) but do not fall into the mistakes we have made in implementing the doctrine. He has evidence that the mistakes are due in part to the fact that there is so much money available for education in America : the mistakes are one of the consequences of success. That cause is not likely to operate in Britain. A deeper cause of the mistakes is that the American man-in-the-street demands the wrong results from education: he measures its efficacy in terms of financial and social success. This debilitating public opinion might not matter in Russia (where also there is education for all) but it does matter in America, and it would matter in Britain. So we should be grateful to $\mathrm{Mr}$. Hutchins for one hint: that in a democracy public opinion can debase educational standards and has done so at some levels in America; and in Britain we would do well to educate the public more diligently than we have hitherto in the purpose of our educational system. But readers of Mr. Hutchins's book who observe a non sequitur between his indictments and the splendid achievements of American scholarship (not only in science and technology but also in history and archæology and even English literature) must not be surprised. Mr. Hutchins has exposed with wit and precision the seamy side of the American educational cloak. $\mathrm{He}$ asks us to agree with him that it is seamy; but we cannot pass judgment on a cloak until we have seen both sides. ERIC Ashby

1 Flexner, "Universities : American, English, German" (Oxford Univ. Press, 1930).

${ }^{2}$ Hofstadter and Hardy, "The Development and Scope of Higher Education in the United States" (Columbia Univ. Press, 1952). - Hofstadter and Metzger, "The Development of Academic Freedom in the United States" (Columbia Univ. Press, 1955). 